\title{
Parametric evaluation of methotrimeprazine-midazolam-ketamine and methotrimeprazine-midazolam-ketamine-xylazine combination in $\operatorname{dogs}^{1}$
}

\author{
Avaliação paramétrica das associações levomepromazina-midazolam-cetamina e \\ levomepromazina-midazolam-cetamina-xilazina em cães
}

\author{
Gustavo José Von Glehn dos Santos², Eduardo Hatschbach ${ }^{3}$, Ewaldo de Mattos Júnior ${ }^{4}$ Flávio Massone ${ }^{5}$ \\ 1. Research developed at "Julio de Mesquita Filho University" (UNESP), Faculty of Veterinary Medicine and Zootechny, Laboratory of \\ Veterinary Anesthesiology. Botucatu, São Paulo, Brazil. \\ 2. PhD, Experimental Anesthesiology and member of Experimental Surgery Group of Faculty of Medicine, Regional University of Gurupi. \\ Tocantins, Brazil. \\ 3. Master, Fellow PhD, Experimental Anesthesiology, UNESP, Faculty of Medicine of Botucatu. São Paulo, Brazil. \\ 4. Veterinarian, Veterinary Anesthesiology Service of Integrated Faculty of Campo Mourão. Paraná, Brazil. \\ 5. PhD, Full Professor, Faculty of Veterinary Medicine and Zootechny Department of Surgery and Veterinary Anesthesiology of Botucatu, \\ São Paulo, Brazil.
}

\begin{abstract}
Purpose: To evaluate the parameters of dogs anesthetized by different dissociative drugs protocols through continuous intravenous infusion. Methods: Thirty healthy dogs of both sexes were assigned randomly to three groups (G1, G2, and G3). G1 was administered with methotrimeprazine as a pre-anesthetic medication, intravenously midazolam-ketamine as bolus for induction and midazolam-ketamine by continuous intravenous infusion for a 60 minute-period of maintenance. G2: the same as for G1. plus an increase in the midazolam dose during maintenance. G3: the same treatment as for G2, plus the addition of xylazine during maintenance. Immediately after induction the anesthetic maintenance started, and measures were taken 15 minutes after pre-medication, at 10 minutes intervals, during maintenance (M0 to M7). Results: Bradycardia, atrioventricular blockage, bradypnea and hypoxemia were shown in G3. G1 and G2 showed a slight hypotension only. Conclusion: There were some advantages by using the continuous intravenous via: no parameters oscillation and reduction in the anesthetic recovery period. The increase in midazolam dose brought about little parametric variations which were greater when xylazine was used, with a consequent hypoxemia, bradyarrhytmia, and decrease in respiratory frequency and minute volume.
\end{abstract}

Key words: Anesthesia. Methotrimeprazine. Midazolam. Xylazine. Dogs.

\section{RESUMO}

Objetivo: Avaliar os parâmetros de cães anestesiados com diferentes protocolos de fármacos dissociativos por infusão intravenosa contínua. Métodos: Foram utilizados 30 cães, machos e fêmeas, clinicamente sadios, distribuídos aleatoriamente em três grupos (G1,G2 e G3) (*)). Em G1 utilizou-se levomepromazina como medicação pré-anestésica (MPA), midazolamcetamina pela via intravenosa em bolus para indução e midazolam-cetamina em infusão intravenosa contínua por 60 minutos para manutenção. Em G2 procedeu-se da mesma forma que em G1 elevando-se, porém, a dose de midazolam durante a manutenção. Em G3 repetiu-se o tratamento empregado em G2, acrescentando-se a xilazina à manutenção. Após a indução, iniciou-se imediatamente a manutenção anestésica, realizando-se aferições, 15 minutos depois da MPA, em intervalos de 10 minutos, durante a manutenção (M0 a M7). Resultados: Em G3 ocorreu bradicardia, bloqueio átrioventricular, bradipnéia e hipoxemia e em G1 e G2, discreta hipotensão. Conclusão: A via intravenosa contínua apresentou vantagens quanto a: não oscilação dos parâmetros e redução no período de recuperação anestésica. A elevação da dose de midazolam resultou em discretas variações paramétricas, estas, acentuadas pelo uso da xilazina, que causou hipoxemia, bradiarritmia, diminuição da freqüência respiratória e volume minuto.

Descritores: Anestesia. Metotrimeprazina. Midazolan. Xilazina. Cães. 


\section{Introduction}

Historically the first studies on intravenously drugs administration were based on Willian Harvey discoveries, in 1628, which involved morphfunctional aspects of the circulatory system. In the mids of the $19^{\text {th }}$ century, those studies advanced with the invention of the syringe and hypodermic needle by Rynd in 1845 and Wood in 1855, respectively. Intravenous anesthesia, in spite of its discovery, half a century ago, still has a high potential for its utilization in the modern anesthesiology. There is no injectable anesthetic that simultaneous and efficiently produces all the compounds of general anesthesia. Frequently, many different pharmacological drug groups are combined to enhance, through synergic mechanisms, the desirable effects of each drug, or even antagonize the secondary undesirable effects of some compounds combination. Dissociative anesthesia's, as phencyclidine derivatives, appeared in 1963, and were not considered as general anesthesia, however, can be used intravenously and, when combined to other drugs produce a suitable balanced anesthesia which offers a worthwhile somatic analgesia to the surgeon. Although largely used in the veterinary anesthesiology routine and experimental procedures, not always these drugs are in agreement with the real objectives, and so an appropriate analgesia, relaxing and hypnosis are not attained. Monitoring of anesthetic procedure, by measurement and observation of physiological parameters is very important during the anesthesiologic routine for it allows a more precise clinical evaluation and anticipation in the perception of disturbs that will result in the procedure quality and risks to the patient. The work was designed to study a multiparametric evaluation of the combination methotrimeprazine-midazolam - ketamine with increasing dosis of midazolam, combined to xylazine, continuously administered intravenously to determine its validity as applied techniques in the veterinary anesthesiology routine and experimental procedures.

\section{Methods}

This research was approved by the Ethic Committee of Animal Experimentation. Thirty dogs, of both sexes, body weight 10 to $21 \mathrm{~kg}$, were assigned randomly to equal groups (G1,G2,G3), and pre-treated with methotrimeprazine, $1.0 \mathrm{mg} /$ $\mathrm{kg}$, and, after 15 minutes, intravenously induced with midazolam and ketamine, 0.2 and $5.0 \mathrm{mg} / \mathrm{kg}$, respectively. Immediately after induction, the anesthetic maintenance was provided to G1 by continuous intravenous administration of the anesthetic combination of $0.2 \mathrm{mg} / \mathrm{kg} / \mathrm{hour}$ midazolam and $15.0 \mathrm{mg} / \mathrm{kg} /$ hour ketamine. For maintenance of G2, 0.4 $\mathrm{mg} / \mathrm{kg} /$ hour midazolam and $15.0 \mathrm{mg} / \mathrm{kg} /$ hour ketamine were used and for G3 maintenance the dosis were $0.4 \mathrm{mg} / \mathrm{kg} /$ hour midazolam, $15.0 \mathrm{mg} / \mathrm{kg} /$ hour ketamine and $1.0 \mathrm{mg} / \mathrm{kg} /$ hour xylazine. For all groups, a infusion period of 60 minutes was followed. The drugs for maintenance were kept in the same syringe and the volume completed with physiological solution up to $20 \mathrm{ml}$. The parameters were collected at the moments: M0, evaluation of the parameters before premedication injection; M1, evaluation of the parameters 15 minutes after pre-medication and immediately before induction; M2-M7, measurement of parameters at each 10 minutes, started immediately after induction and start of continuous infusion. For the statistical analysis the Software SPSS 12,0 for Windows Advanced was used, by the profile analysis method for $\mathrm{P}<0,05{ }^{8}$

\section{Results}

There was a slight decrease in rectal temperature (RT) in all groups, not significant or of any clinical importance (Figure 1). There were no alterations in respiratory frequency (RF) along the moments, but G3 showed bradypnea when compared to G1 and G2 (Figure 2). The behavior of cardiac frequency (CF) in $\mathrm{G} 1$ was similar to $\mathrm{G} 2$, with an initial decrease and a posterior increase. There was a progressive decrease in G3 but stabilized slightly below normal physiological values (Figure 3).

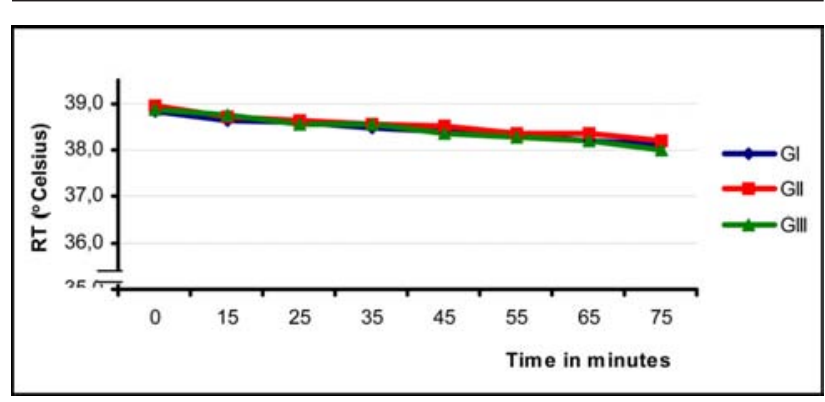

FIGURE 1 - Physiological behavior of rectal temperature, for G1, G2, and G3

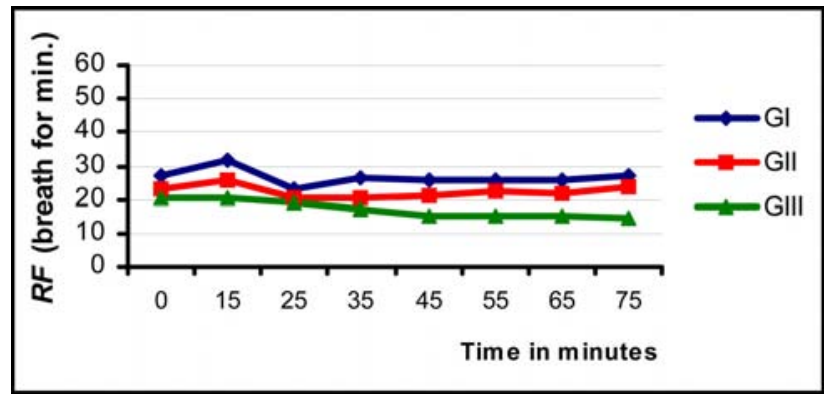

FIGURE 2 - Physiological behavior of respiratory frequency for G1, G2, and G3

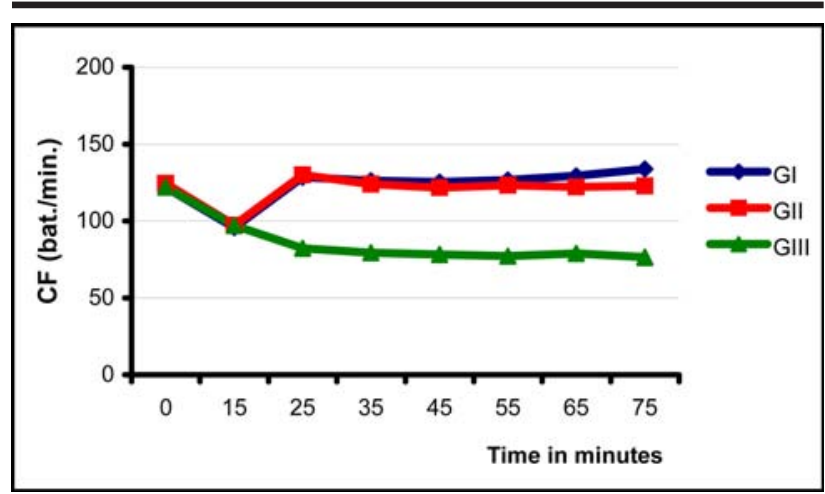

FIGURE 3 - Physiological behavior of cardiac frequency for G1, G2, and G3 
The tidal volume $\left(\mathrm{V}_{\mathrm{T}}\right)$ as well as the minute volume $\left(\mathrm{V}_{\mathrm{M}}\right)$ have not showed any variations along the moments, even when groups were compared (Figures 4 and 5).

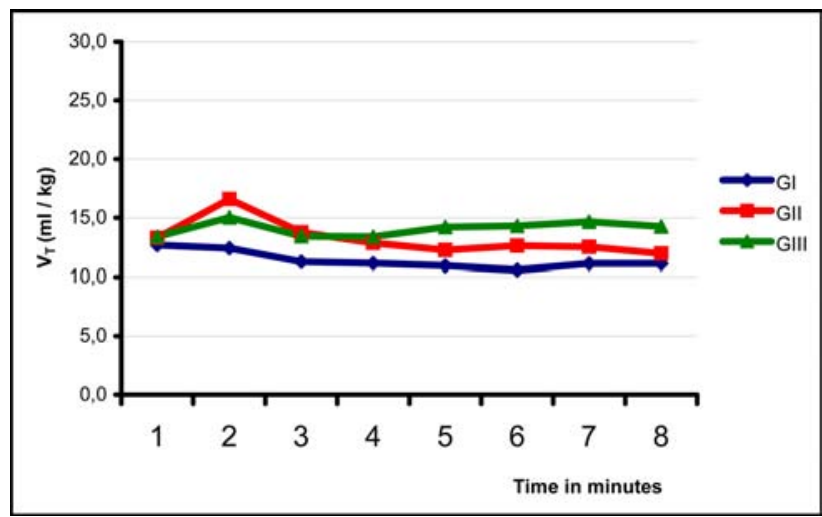

FIGURE 4 - Physiological behavior of tidal volume (VT) for G1, G2, and G3

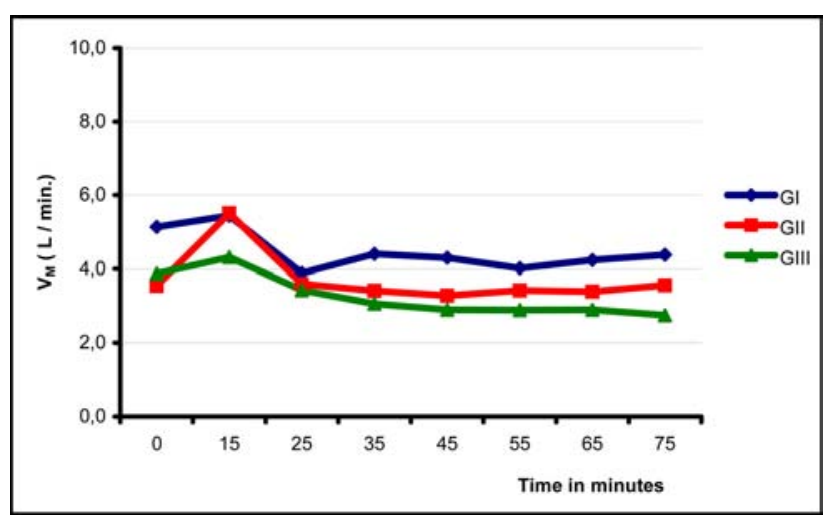

FIGURE 5 - Physiological behavior of minute volume (VM) for G1, G2, and G3

The values at the end of expiration were higher for G3, while for G1 and G2 were within the normal limits but the saturation of oxygen was lower in G3 (Figures 6 and 7). The systolic arterial pressure (SAP), mean arterial pressure (MAP) and diastolic arterial pressure (DAP) had a similar behavior, and in G1 and G2 a progressive decrease up to M2 occurred, with a posterior stabilization in the lower limits, and a slight hypotension. G3 showed an initial parameter decrease, a posterior increase and stabilized from M2 (Figure 8). Anesthetic recovery was first observed in G1 at approximately 38 minutes after the end of anesthetic drugs infusion, 50 minutes in G2 and 56 minutes in G3 respiratory frequency and cardiac frequency, for G1, G2, and G3. Alls parametrics variations was expressed in Table 1.

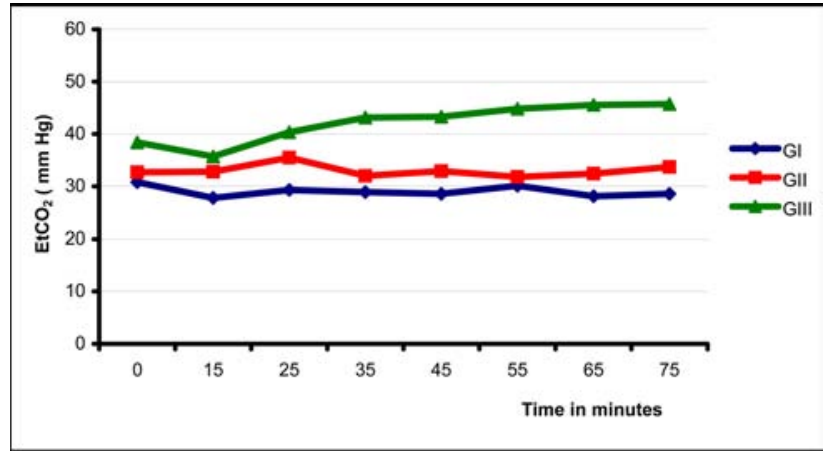

FIGURE 6 - Physiological behavior of $\mathrm{CO}_{2}$ tension $\left(\mathrm{EtCO}_{2}\right)$ for G1, G2, and G3

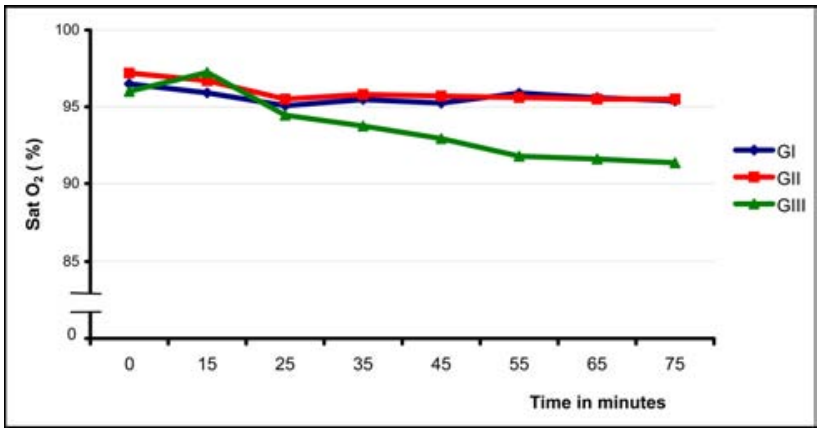

FIGURE 7 - Physiological behavior of saturation of oxygen $\left(\mathrm{SatO}_{2}\right)$ for G1, G2, and G3

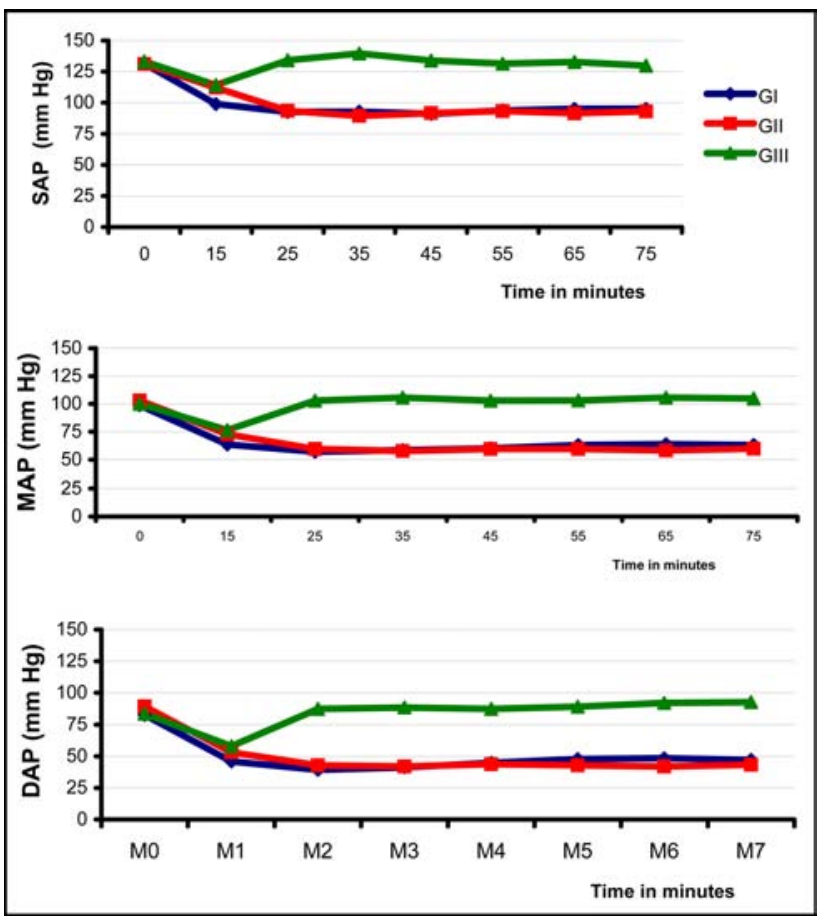

FIGURE 8 - Physiological behavior of, systolic, mean and diastolic arterial pressure, for G1, G2, and G3 
TABLE 1 - Parametric variation in dogs treated with methotrimeprazine, midazolam and ketamine (G1); methotrimeprazine-midazolam, with a different dose, and ketamine (G2) and methotrimeprazinemidazolam-ketamine and xylazine (G3) at different moments

\begin{tabular}{|c|c|c|c|c|c|c|c|c|c|}
\hline & Groups & M0 & M1 & M2 & M3 & M4 & M5 & M6 & M7 \\
\hline \multirow{3}{*}{$\begin{array}{l}\text { RT } \\
\left({ }^{\circ} \mathrm{C}\right)\end{array}$} & GI & $38,9 \pm 0,4^{\mathrm{a}}$ & $38,7 \pm 0,4^{\mathrm{a}}$ & $38,6 \pm 0,5^{\mathrm{a}}$ & $38,5 \pm 0,5^{\mathrm{a}}$ & $38,3 \pm 0,7^{\mathrm{a}}$ & $38,3 \pm 0,8^{\mathrm{a}}$ & $38,2 \pm 0,9^{\mathrm{a}}$ & $38 \pm 1,1^{\mathrm{a}}$ \\
\hline & GII & $39 \pm 0,3^{\mathrm{a}}$ & $38,7 \pm 0,4^{\mathrm{a}}$ & $38,6 \pm 0,6^{a}$ & $38,5 \pm 0,6^{\mathrm{a}}$ & $38,5 \pm 0,6^{\mathrm{a}}$ & $38,4 \pm 0,6^{a}$ & $38,4 \pm 0,6^{\mathrm{a}}$ & $38,2 \pm 0,6^{\mathrm{a}}$ \\
\hline & GIII & $38,9 \pm 0,4^{\mathrm{a}}$ & $38,7 \pm 0,4^{\mathrm{a}}$ & $38,6 \pm 0,5^{\mathrm{a}}$ & $38,5 \pm 0,5^{\mathrm{a}}$ & $38,3 \pm 0,7^{\mathrm{a}}$ & $38,3 \pm 0,8^{\mathrm{a}}$ & $38,2 \pm 0,9^{\mathrm{a}}$ & $38 \pm 1,1^{\mathrm{a}}$ \\
\hline \multirow{3}{*}{$\begin{array}{c}\mathrm{RF} \\
\text { (breaths/min) }\end{array}$} & GI & $27 \pm 7^{\mathrm{a}}$ & $31 \pm 19^{\mathrm{a}}$ & $23 \pm 7^{\mathrm{a}}$ & $26 \pm 8^{\mathrm{a}}$ & $26 \pm 8^{\mathrm{a}}$ & $26 \pm 9^{\mathrm{a}}$ & $26 \pm 9^{\mathrm{a}}$ & $27 \pm 10^{a}$ \\
\hline & GII & $23 \pm 6^{\mathrm{a}}$ & $26 \pm 15^{\mathrm{a}}$ & $20 \pm 7^{\mathrm{a}}$ & $21 \pm 7^{\mathrm{a}}$ & $21 \pm 7^{\mathrm{a}}$ & $22 \pm 9^{a}$ & $22 \pm 8^{a}$ & $24 \pm 7^{\mathrm{a}}$ \\
\hline & GIII * & $20 \pm 5^{\mathrm{a}}$ & $20 \pm 5^{\mathrm{a}}$ & $19 \pm 6^{\mathrm{a}}$ & $17 \pm 6^{\mathrm{a}}$ & $15 \pm 6^{\mathrm{a}}$ & $15 \pm 6^{\mathrm{a}}$ & $15 \pm 5^{\mathrm{a}}$ & $14 \pm 4^{\mathrm{a}}$ \\
\hline \multirow{3}{*}{$\begin{array}{c}\mathrm{V}_{\mathrm{T}} \\
(\mathrm{ml} / \mathrm{kg})\end{array}$} & GI & $12,7 \pm 2,8^{a}$ & $12,4 \pm 4,7^{\mathrm{a}}$ & $11,2 \pm 3,1^{\mathrm{a}}$ & $11,1 \pm 3,7^{\mathrm{a}}$ & $10,9 \pm 3,2^{\mathrm{a}}$ & $10,6 \pm 2,9^{a}$ & $11,1 \pm 4^{\mathrm{a}}$ & $11,1 \pm 3,9^{\mathrm{a}}$ \\
\hline & GII & $13,3 \pm 3^{\mathrm{a}}$ & $16,6 \pm 4,4^{\mathrm{a}}$ & $13,8 \pm 4,2^{a}$ & $12,8 \pm 3,9^{\mathrm{a}}$ & $12,2 \pm 4,2^{\mathrm{a}}$ & $12,6 \pm 4,9^{a}$ & $12,5 \pm 4,3^{\mathrm{a}}$ & $12 \pm 4,7^{\mathrm{a}}$ \\
\hline & GIII & $13,4 \pm 1,7^{\mathrm{a}}$ & $15 \pm 3,5^{\mathrm{a}}$ & $13,4 \pm 2,8^{\mathrm{a}}$ & $13,4 \pm 3,5^{\mathrm{a}}$ & $14,2 \pm 4^{\mathrm{a}}$ & $14,3 \pm 4,3^{\mathrm{a}}$ & $14,6 \pm 3,7^{\mathrm{a}}$ & $14,2 \pm 3,5^{\mathrm{a}}$ \\
\hline \multirow{3}{*}{$\begin{array}{c}\mathrm{V}_{\mathrm{M}} \\
(1 / \mathrm{min})\end{array}$} & GI & $5,1 \pm 2,1^{\mathrm{a}}$ & $5,4 \pm 3,6^{\mathrm{a}}$ & $3,9 \pm 1,9^{\mathrm{a}}$ & $4,4 \pm 2,5^{\mathrm{a}}$ & $4,3 \pm 2,3^{\mathrm{a}}$ & $4 \pm 2,1^{\mathrm{a}}$ & $4,2 \pm 2,5^{\mathrm{a}}$ & $4,4 \pm 2,4^{a}$ \\
\hline & GII & $3,5 \pm 1,2^{\mathrm{a}}$ & $5,5 \pm 2^{b}$ & $3,6 \pm 1,1^{\mathrm{a}}$ & $3,4 \pm 0,9^{\mathrm{a}}$ & $3,3 \pm 0,9^{\mathrm{a}}$ & $3,4 \pm 0,9^{\mathrm{a}}$ & $3,4 \pm 0,9^{a}$ & $3,6 \pm 0,9^{a}$ \\
\hline & GIII & $3,9 \pm 1,1^{\mathrm{a}}$ & $4,3 \pm 1,4^{\mathrm{a}}$ & $3,4 \pm 0,8^{\mathrm{a}}$ & $3,1 \pm 0,7^{\mathrm{a}}$ & $2,9 \pm 0,7^{\mathrm{a}}$ & $2,9 \pm 0,7^{\mathrm{a}}$ & $2,9 \pm 0,5^{\mathrm{a}}$ & $2,7 \pm 0,4^{\mathrm{a}}$ \\
\hline \multirow{3}{*}{$\begin{array}{c}\text { Sat } \mathrm{O}_{2} \\
(\%)\end{array}$} & GI & $97 \pm 2^{a}$ & $96 \pm 2^{a}$ & $95 \pm 2^{\mathrm{a}}$ & $95 \pm 2^{\mathrm{a}}$ & $95 \pm 2^{\mathrm{a}}$ & $96 \pm 2^{a}$ & $96 \pm 2^{a}$ & $95 \pm 2^{\mathrm{a}}$ \\
\hline & GII & $97 \pm 1^{\text {a }}$ & $97 \pm 2^{a}$ & $96 \pm 2^{\mathrm{a}}$ & $96 \pm 2^{a}$ & $96 \pm 2^{a}$ & $96 \pm 2^{a}$ & $96 \pm 2^{a}$ & $96 \pm 2^{a}$ \\
\hline & GIII & $96 \pm 3^{a}$ & $97 \pm 1^{\text {a }}$ & $94 \pm 3^{a}$ & $94 \pm 4^{\mathrm{a}}$ & $93 \pm 5^{\mathrm{a}}$ & $92 \pm 5^{\mathrm{a}}$ & $92 \pm 6^{\mathrm{a}}$ & $91 \pm 5^{\mathrm{a}}$ \\
\hline \multirow{3}{*}{$\begin{array}{c}\mathrm{EtCO}_{2} \\
(\mathrm{mmHg})\end{array}$} & GI & $31 \pm 8^{\mathrm{a}}$ & $28 \pm 7^{\mathrm{a}}$ & $29 \pm 8^{a}$ & $29 \pm 8^{\mathrm{a}}$ & $29 \pm 9^{\mathrm{a}}$ & $30 \pm 7^{\mathrm{a}}$ & $28 \pm 7^{\mathrm{a}}$ & $29 \pm 7^{\mathrm{a}}$ \\
\hline & GII & $33 \pm 9^{a}$ & $33 \pm 10^{a}$ & $36 \pm 10^{a}$ & $32 \pm 10^{\mathrm{a}}$ & $33 \pm 10^{a}$ & $32 \pm 10^{a}$ & $32 \pm 10^{a}$ & $34 \pm 10^{\mathrm{a}}$ \\
\hline & GIII * & $38 \pm 4^{\mathrm{a}}$ & $36 \pm 5^{\mathrm{a}}$ & $40 \pm 6^{\mathrm{a}}$ & $43 \pm 5^{\mathrm{a}}$ & $43 \pm 5^{\mathrm{a}}$ & $45 \pm 5^{\mathrm{a}}$ & $46 \pm 6^{\mathrm{a}}$ & $46 \pm 6^{\mathrm{a}}$ \\
\hline \multirow{3}{*}{$\begin{array}{c}\mathrm{CF} \\
\text { (beats/min) }\end{array}$} & GI & $122 \pm 15^{\mathrm{a}}$ & $96 \pm 17^{b}$ & $128 \pm 10^{\mathrm{a}}$ & $126 \pm 14^{a}$ & $125 \pm 14^{\mathrm{a}}$ & $127 \pm 16^{\mathrm{a}}$ & $129 \pm 14^{a}$ & $134 \pm 15^{a}$ \\
\hline & GII & $124 \pm 24^{\mathrm{a}}$ & $97 \pm 18^{b}$ & $130 \pm 20^{\mathrm{a}}$ & $124 \pm 22^{\mathrm{a}}$ & $122 \pm 22^{\mathrm{a}}$ & $123 \pm 23^{a}$ & $122 \pm 19^{\mathrm{a}}$ & $123 \pm 16^{\mathrm{a}}$ \\
\hline & GIII * & $122 \pm 15^{\mathrm{a}}$ & $97 \pm 14^{\mathrm{b}}$ & $82 \pm 14^{b}$ & $79 \pm 12^{b}$ & $78 \pm 14^{b}$ & $77 \pm 14^{b}$ & $79 \pm 12^{b}$ & $76 \pm 13^{b}$ \\
\hline \multirow{3}{*}{$\begin{array}{c}\text { SAP } \\
(\mathrm{mmHg})\end{array}$} & GI & $131 \pm 18^{\mathrm{a}}$ & $99 \pm 14^{b}$ & $93 \pm 8^{b}$ & $93 \pm 6^{b}$ & $91 \pm 6^{b}$ & $94 \pm 4^{b}$ & $95 \pm 7^{b}$ & $95 \pm 6^{b}$ \\
\hline & GII & $131 \pm 15^{\mathrm{a}}$ & $112 \pm 16^{b}$ & $94 \pm 10^{\mathrm{c}}$ & $89 \pm 11^{\mathrm{c}}$ & $92 \pm 10^{c}$ & $93 \pm 9^{c}$ & $91 \pm 8^{c}$ & $93 \pm 7^{\mathrm{c}}$ \\
\hline & GIII * & $133 \pm 13^{a}$ & $114 \pm 13^{b}$ & $134 \pm 9^{\mathrm{a}}$ & $140 \pm 13^{\mathrm{a}}$ & $134 \pm 14^{\mathrm{a}}$ & $131 \pm 14^{\mathrm{a}}$ & $133 \pm 14^{\mathrm{a}}$ & $130 \pm 14^{\mathrm{a}}$ \\
\hline \multirow{3}{*}{$\begin{array}{c}\text { MAP } \\
(\mathrm{mmHg})\end{array}$} & GI & $99 \pm 15^{\mathrm{a}}$ & $64 \pm 13^{b}$ & $57 \pm 7^{b}$ & $58 \pm 7^{b}$ & $60 \pm 5^{\mathrm{b}}$ & $63 \pm 6^{b}$ & $64 \pm 7^{b}$ & $63 \pm 11^{b}$ \\
\hline & GII & $103 \pm 16^{a}$ & $73 \pm 11^{\mathrm{b}}$ & $60 \pm 9^{b}$ & $58 \pm 12^{b}$ & $60 \pm 9^{b}$ & $60 \pm 9^{\mathrm{b}}$ & $58 \pm 9^{\mathrm{b}}$ & $60 \pm 9^{b}$ \\
\hline & GIII * & $100 \pm 9^{a}$ & $77 \pm 15^{b}$ & $103 \pm 10^{\mathrm{a}}$ & $106 \pm 11^{\mathrm{a}}$ & $103 \pm 11^{\mathrm{a}}$ & $103 \pm 13^{a}$ & $106 \pm 13^{a}$ & $105 \pm 13^{a}$ \\
\hline \multirow{3}{*}{$\begin{array}{c}\text { DAP } \\
(\mathrm{mmHg})\end{array}$} & GI & $83 \pm 14^{a}$ & $46 \pm 14^{b}$ & $39 \pm 7^{b}$ & $41 \pm 10^{b}$ & $45 \pm 8^{b}$ & $48 \pm 8^{b}$ & $48 \pm 9^{b}$ & $47 \pm 14^{b}$ \\
\hline & GII & $89 \pm 19^{a}$ & $53 \pm 11^{b}$ & $43 \pm 11^{b}$ & $42 \pm 13^{b}$ & $44 \pm 11^{b}$ & $43 \pm 10^{b}$ & $42 \pm 11^{b}$ & $43 \pm 10^{b}$ \\
\hline & GIII * & $84 \pm 12^{a}$ & $58 \pm 18^{b}$ & $87 \pm 12^{a}$ & $89 \pm 12^{a}$ & $87 \pm 11^{a}$ & $89 \pm 14^{\mathrm{a}}$ & $92 \pm 15^{a}$ & $93 \pm 14^{\mathrm{a}}$ \\
\hline
\end{tabular}

* Significant differences among treatments along the moments $(\mathrm{P}<0.05)$

abc Significant differences among moments within each treatment $(\mathrm{P}<0.05)$

\section{Discussion}

The little and gradual decrease in RT was not clinically important, however could be due to ketamine, which can lead to an alteration in thermoregulation by directly depressing the thermoregulation center in the hypothalamus. It is suggested, however, that the progressive decrease in rectal temperature could be due to methotrimeprazine and xylazine action as hypotensors and depressors of central nervous system. This effect was not considered, therefore, for benzodiazepines cause little variations on this parameter, what was observed in this experiment when different dosis of midazolam were utilized. The RF values were within the physiological limits and the slight decrease in G3 showed the influence of xylazine on the anesthetic combination, for it depresses the respiratory center, reducing its sensitivity to the increase of $\mathrm{PaCO}_{2}$, resulting in a decrease in $\mathrm{RF}$ and $\mathrm{M}_{\mathrm{v}}$. Furthermore, the lowest $\mathrm{RF}$ attained in G3 can, also, be combined not only to xylazine but to the simultaneous use of midazolam, as well, due to its depressing effect on dose-dependent respiratory function. The lower RF in G3 compared to G1 could be due to the increase of midazolam dose, for this drug increases the ketamine depression effects on respiration. Yet, there was no greater oscillation during the anesthetic maintenance period and, therefore, the continuous intravenous infusion has not caused great parameters oscillation along the moments. During the period of anesthetic maintenance, $\mathrm{G} 1$ showed lower values for $\mathrm{T}_{\mathrm{V}}$ when compared to G2, and both groups compared to G3. This phenomenon could be due to a physiological compensatory mechanism, resulting from the reduction in $\mathrm{RF}$, and so, the animal responds 
with an increase in $\mathrm{T}_{\mathrm{V}}$, in an attempt to keep the ventilation function. This effect may be based on the fact that both xylazine and midazolam are potential depressors of respiratory function and, moreover, the increase in $\mathrm{V}_{\mathrm{T}}$ followed the increase in midazolam dose and addition of xylazine ${ }^{910,11,12,13,14}$. However, there was no effect of dose-dependent hypotension for G1, G2 has not varied in a significant way, and there were not any significant differences between the two groups, showing the little influence of the midazolam dose increase on this parameter. The maintenance of MAP, even with low values, after the induction and maintenance employed in G1 and G2 showed that ketamine was not able to efficiently antagonize the effects brought about by methotrimeprazine used in PAM. There was an increase of MAP in G3 but still within the normal limits, what could be explained by the action of xylazine on a-1 receptors because it is not specific to a-2 receptors. As for DAP an G2 values were below lower physiological limits, and so a diastolic arterial hypotension occurred in the animals subjected to methotrimeprazine -midazolam-ketamine only (even with different dosis of midazolam) and may be considered as hypotension effects due to benzodiazepines and fenothiazinics, as reported before. The increase in DAP in G3 was due to the same reasons reported before, when xylazine was used, showing the xylazine superposition effect on fenothiazinics and benzodiazepines drugs. It must be emphasized that this increase in arterial pressure due to xylazine occurs as a function of a peripheral vasoconstriction brought about by a- 1 receptors stimulation, and it must be evaluated very well as long as reduction of $\mathrm{SatO}_{2}$ and $\mathrm{V}_{\mathrm{M}}$ is simultaneously occurring. As for electrocardiography, it is known that dissociative drugs change this function in order to increase the CF without leading to disturbs in rhythmicity. This effect was observed through electrocardiography especially in G1 and G2 which showed a CF above 120 beats/min. In these groups, the increase in CF was a function of sympathetic stimulation brought about by the dissociative drugs, as reported before. There were no electrocardiographic alterations as for the cardiac rhythm in the animals of G1 and G2. Adecrease in the CF, sinusal rhythm variation (in all animals of the group) and atrioventricular blockage (in two animals of the group) was observed. The decrease in CF was caused by the utilization of xylazine, as reported before. These effects were explained by the xylazine action bringing about a slight bradycardia and an atrioventricular blockage, which are classified as degrees first, second and third, even with lower dosis. The fenothiazinics have been proposed as antiarrhythmgenics ${ }^{12,18,19}$. However, this effect was not totally efficient, as long as two animals showed atrioventricular blockage when xylazine, midazolam and ketamine were continuously and intravenously used. When the recovery period of animals treated with methotrimeprazine-midazolam-ketamine through intramuscular and intravenous via were compared, it was observed a reduction in the same period when the second via was utilized. Santos ${ }^{11}$ describes an anesthetic recovery of 76 minutes for dogs treated with the combination above mentioned, via intramuscular, and 38 minutes with continuous infusion, event also reported by Rosa and Massone ${ }^{21}$. The decrease in CF in G3 was considered due, not only to the methotrimeprazine use in the pre-anesthetic medication, but also and mainly to the use of xylazine. An important effect of xylazine is the decrease in CF due to a sympathetic depression caused by the adrenergic a-2 receptors with a superposition of this effect on the tachycardics effect of ketamine. This is in agreement with the results found by Luna et $\mathrm{al}^{12}$ and Santos et $\mathrm{al}^{6}$ who obtained lower values for CF, by using intramuscular xylazine, when compared to dissociative drugs and benzodiazepinics. There was an initial reduction of SAP immediately after administration of the preanesthetic medication, methotrimeprazine, utilized in all groups that might be caused by this fenothiazine adrenolytic function. The ketamine leads to an increase in arterial pressure as a function of peripheral vasoconstriction and so, not recommended for hypertension patients ${ }^{13,15,16}$ However, this effect was not observed in G1 and G2, and, therefore, ketamine was not able to efficiently antagonize the hypotension effects brought about by methotrimeprazine The decrease in SAP was not considered as due to midazolam addition, as long as there was not any significant difference between the lowest and the highest dosis of midazolam utilized in G1 and G2. As there was an increase in SAP in G3, it was possible to realize that the effects of xylazine on the increase of pressure during the continuous infusion, overcame the hypotension effects of methotrimeprazine used as a pre-anesthetic medication. According to Spinoza and Spinoza ${ }^{9}$ this increase in arterial pressure is caused by the a-2 receptors stimulation, as long as xylazine has not $100 \%$ specificity on a- 2 receptors. The increase in SAP in G3 was below the physiologic values but, on the other hand, the combinations used in G1 and G2 showed slightly low values and, therefore, considered as a light hypotension. As for MAP the values for G1 and G2 showed a little hypotension in the animals treated with methotrimeprazine -midazolam-ketamine only, and were considered as hypotension effects of methotrimeprazine as a pre-anesthetic medication. Forster et $\mathrm{al}^{10}$ reported hypotension effects caused by midazolam when used through intravenous dose-dependent via. In all groups the greatest reduction in $\mathrm{M}_{\mathrm{v}}$ was shown in G3, probably influenced by xylazine in combination with midazolam. The littlest reduction occurred in G1 when compared to G2, was in agreement with the increase in midazolam dose in the combination administered via continuous infusion, related to the depressor effect of this drug on the RF. There were no significant variations for $\mathrm{SatO}_{2}$; however a physiological progressive saturation reduction of the parameter occurred from M1 on, about 94 and 91, considered as hypoxemia, important for the anesthesiologist. Taking into consideration the low respiratory depression brought about by dissociative drugs, it is suggested that the decrease in $\mathrm{SatO}_{2}$, in dogs treated with different dissociative anesthesia protocols, was caused by adjuvant drugs of the combination, specially xylazine, as long as when midazolam dose was increased, no variations occurred ${ }^{13,15}$. In G1 and G2 there was no difference as for $\mathrm{EtCO}_{2}$, with values below $36 \mathrm{~mm} \mathrm{Hg}$. The group treated with xylazine showed values higher than the above mentioned ones, and this event could be explained as related to alterations caused by xylazine which result in a decrease of $M_{v}$ and reduction of Sat02, as reported by Luna et al. ${ }^{12}$ and Santos (2003) ${ }^{11}$ who utilized xylazine and ketamine by intramuscular via. AEtCO slightly higher was observed in $\mathrm{G} 2$ when compared to G1, probably influenced by the reduction effects on Mv, due to midazolam higher dose. The behavior of CF varied for the ketamine-midazolam and ketamine-midazolam-xylazine groups. The variations found in both groups (G1-G2) and (G3) are very close to the physiological upper and lower limits, 
respectively. The increase in the midazolam dose used in G2 resulted in a non- significant difference for $\mathrm{CF}$, when compared to the lower dose used in G1, and, therefore benzodiazepines have little influence on the cardiac function. The initial decrease in CF in all groups could be related to a sympatholytic effect of methotrimeprazine. However, sometimes a positive chronotropic effect may occur when methotrimeprazine is used, and this effect is consequent of a reflex response to the hypotension that appears with its utilization ${ }^{8}$.

\section{Conclusion}

1. The increase in midazolam dose caused little parametric variations, which were due to the xylazine use leading to hypoxemia, bradyarrithmia and bradypnea with reduction in the minute volume;

2. Ketamine was unable to control hypotension caused by methotrimeprazine in G1 and G2;

3. Continuous intravenous infusion of dissociative drugs resulted in a little parametric oscillation, and reduction in the pre-anesthetic recovery period;

4. Techniques employed in GI and GII had an advantage as for chemical restraint and allowed manipulation but not cruel.

\section{References}

1. Wood A. A new method of treating neuralgia by direct application of opiates to the painful points. Edinburgh Med Surg. 1855; 82: 265-81.

2. Bailey JM. A technique for approximately maintaining constant plasma levels of intravenous drougs. Anesthesiology. 1993; 78: 116-23.

3. Winters WD, Ferraz-Allado T, Gusman-Flores C, Alacaraz $\mathrm{M}$. The cataleptic states induced by ketamine: a review of the neuropharmacology of anesthesia. Neuropharmacology. 1972; 11:303-15.

4. Wright M. Pharmacologic effectes of ketamine and its use in veterinary medicine. J Am Vet Med Assoc. 1982; 180: 1462-70.

5. Dupras J, Vachon P, Cuvelliez S, Blais D. Anestesia of the New Zeland rabbit using the combination of tiletaminezolazepam and ketamine-midazolam with or without xilazine. Can Vet J. 2001; 42:455-60.

6. Santos GJG, Massone F, Mattos Junior E, Trinca LA. Avaliação cardiovascular de cães submetidos à associações anestésicas fundamentadas em fármacos dissociativos Rev Cient Med Vet PeqAnim. 2004; 2 (8): 276-84.
7. Curi PR. Análise de medidas repetidas em experimentos biológicos. Rev Bras Estat. 1980;41:137-45.

8. Massone F, Bernis WO. Efeitos da pré-medicação com levomepromazina na anestesia pelo pentobarbital sódico em cães. Arq Esc Vet. 1976; 28(1): 43-51.

9. Spinosa HS, Spinosa FRNS. Sobre os efeitos farmacológicos da xilazina. Biotemas. 1991; 4: 111-22.

10. Forster A, Gardaz JP, Suter PM. Respiratory depression by midazolam and diazepam. Anesthesiology. 1980; 53: 494-7.

11. Santos GJG. Avaliação paramétrica das associações anestésicas: atropina-xilazina-cetamina, levomepromazinazolazepam-tiletamina e levomepromazina-midazolamcetamina em cães. Aspectos nociceptivos e índice bispectral. [Dissertação]. Faculdade de Medicina Veterinária e Zootecnia, Universidade Estadual Paulista; 2003.

12. Luna SPL, Nogueira CS, Cruz ML, Massone F, Castro GB. Romifidine or xylazine combined with ketamine in dogs premedicated with methrotrimepromazine. Braz J Res Anim Sci. 2000; 3: 19-25.

13. Haskins FC, Farver TM, Patz JD. Cardiovascular changes in dogs given diazepam and diazepam-ketamine. Am J Vet Res.1986; 47:795-8.

14. Cistola AM, Golder FJ, Centenzone LA, Mckay LW, Levy JK. Anesthetic and physiologic effects of tiletamine, zolazepam, ketamine and xylazine combination (TKX) in feral cats undergoing surgical sterilization. J Feline Med Surg. 2004(6): 297-303.

15. Haskins FC, Farver TM, Patz JD. Ketamine in dogs. Am J Vet Res.1985; 46:1855-60.

16. Brown SA, Jacobson JD, Hartsfield SM. Pharmacokinetics of midazolam administered concurrently with ketamine after intravenous bolus or infusion in dogs. J Vet Pharmacol Ther. 1993; 16: 419-25.

18. Souza AP, Carareto R, Nunes N, Leite AV, Paula DP. Eletrocardiografia de cães anestesiados com cetamina-S ou cetamina. Cienc Rural. 2002; 32 (5): 787-791.

19. Dyson D, Pettifer G. Evaluation of the arrhythmogenicity of a low dose of acepromazine: comparison with xylazine. Can J Vet Res. 1997; 61:241-5.

20. Rezende ML, Farias A, Bolzan AA, Ferreira WL, Léga E, Nunes N. Levomepromazina e acepromazina no bloqueio da arritmia induzida pela. adrenalina em cães anestesiados pelo halotano. Cienc Rural. 2002; 32: 787-791

21. Rosa AL, Massone F. Avaliação algimétrica por estímulo nociceptivo térmico e pressórico em cães pré-tratados com levomepromazina, midazolam e quetamina associados ou não ao butorfanol e buprenorfina. Acta Cir Bras. São Paulo; 2005; 20(1): 39-45.
Correspondence:

Flavio Massone

R. Antônio Amaral César, 186

18611-344 Botucatu - SP Brazil

btflama@uol.com.br
Conflict of interest: none

Financial source: CAPES and CNPq

Received: April 11, 2006

Review: May 09, 2006

Accepted: June 13, 2006

\section{How to cite this article:}

Santos GJVG, Hatschbach E, Mattos Jr E, Massone F. Parametric evaluation of methotrimeprazine-midazolam-ketamine and methotrimeprazine-midazolam-ketamine-xylazine combination in dogs. Acta Cir Bras. [serial on the Internet] 2006 SeptOct;21(5). Available from URL: http://www.scielo.br/acb. 